\title{
A MODEL OF ISLAMIC TEACHER EDUCATION FOR SOCIAL JUSTICE IN INDONESIA A Critical Pedagogy Perspective
}

\author{
Raihani | UIN Sultan Syarif Kasim Riau - Indonesia \\ raihani@uin-suska.ac.id
}

\begin{abstract}
This paper proposes a model for teacher preparation in the context of Islamic education using a critical pedagogy perspective. The constantly increasing social injustice combined with sectarian frictions has placed Indonesian society in a fragile situation and, it, therefore, needs a closer attention, and more so in the field of education. This paper argues that reforms in education should begin from the very vital component of education, i.e. teacher since teacher contributes significantly to the development of students in almost all aspects. Also, the traditional approach of instruction does not seem able to provide solutions for most of the social problems, even though Islamic teachings strongly endorse equality, justice, and respect for differences. This conceptual paper, therefore, develops a model for reforms in teacher education starting from philosophical foundation of teaching to critical pedagogy practices. In this paper, this critical pedagogy approach is argued to enable teachers to become change agents for promoting education for social justice.
\end{abstract}

Keywords: Critical pedagogy, teacher education, Islamic university, social justice

\section{Introduction}

With more than 250 million populations, Indonesia is made the largest archipelagic nation in the world. It consists of more than 13,000 islands - large and small. It is a richly diverse country in terms of ethnicity, culture, and religion or faith. Muslims constitute the majority among other religious believers including Christians, Hindus, Buddhists and Confucians. For long, Indonesia has been described as a country with a good record of diversity and tolerance. Yet, this does 
not negate events of which this reputation was somewhat undermined. Ethnic and religious conflicts have sparked between groups and attracted serious attention. In the post-reform era, i.e. after 1998, when openness and democratization have been applied in both social and political spheres, the situation has even been worse as the rise of identity politics - segregating people of differences more - has been intensifying. 1 In addition to this ethnic and religious diversity, Indonesian people are also diverse in terms of socio-economic backgrounds. The Gini Ratio remains high in 2016, which is 0.394 indicating a wide gap between the rich and the poor despite efforts by government to improve people's welfare. ${ }^{2}$

To some extent, such a diversity has now created or implied problems. One of the problems, as this paper is concerned, is social injustice in the education context. Raihani has conducted about this issue in different school settings and found that not every student is treated equally. ${ }^{3}$ For example, students of minority religions experience discrimination in the access to their religious teachings and deprivation from their religious practices at schools. By minority here, I do not mean the smaller number of religious population in the whole context of Indonesia, but minority in particular places such as Muslims in Central Kalimantan or even in a more micro school context. ${ }^{4}$ In a public school in Batam, the principal with the approval of teachers issued a policy to restrict the number of students from a particular ethnic and religious background. Another example of social injustice found in school is the created differentiating image of certain academic streams. The Natural Sciences stream is considered more prestigious with its students described as more diligent and smarter ones. In contrast, the Social Sciences stream and its students are

1 Smith Claire, The Roots of Violence and Prospects for Reconciliation: A Case Study of Ethnic Conflict in Central Kalimantan, Indonesia (Washington, DC: The World Bank, 2005), pp. 510; Chris Wilson, Ethno-Religious Violence in Indonesia: From Soil to God (London: Routledge, Taylor \& Francis Group, 2008), p. 25.

2 The World Bank, Indonesia's Rising Divide (Jakarta: The World Bank, 2016), p. 3.

3 Raihani, Creating Multicultural Citizens: A Portrayal of Contemporary Indonesian Education (New York: Routledge, 2014), pp. 85-107; Lyn Parker and Chang Yau Hoon, "Secularity, Religion and the Possibilities for Religious Citizenship," Asian Journal of Social Science, 41 (2013), pp. 150-174.

4 Raihani, "Education for Multicultural Citizens in Indonesia: Policies and Practices," Compare: A Journal of Comparative and International Education, 48, 6 (2018), pp. 992-1009. 
regarded as a second class group. Students of this disadvantaged group not only suffer from differentiation by teachers but also from parents. ${ }^{5}$ As a university teacher at an Islamic education faculty, I have also seen anecdotal evidence of unjust attitudes of students towards differences and their experiences of being discriminated. In one of my classes, students were not only composited of Muslims, but also a couple of Christians. In my observation, when discussing about religious concepts and the non-Muslims were asked to speak of such concepts of their faith, Muslims students always laughed and mocked them. Another anecdotal evidence also suggests that discrimination not only happens to students of religious minority, but also to those of ethnic backgrounds which are different from that of people in power. The question "where are you from" to students had become an indication of discriminating practices in academic and administrative services.

In a macro context, namely the current Indonesian society, social injustice and discrimination remain a chronical problem that can constantly be seen in a day-to-day life. Both injustice and discrimination can either be driven by structure or culture. Structural injustice and discrimination represent an unfair treatment of groups and individuals by the system of governance and administration such as the partiality of law towards marginalized groups or individuals ${ }^{6}$ and the deprivation of religious minority access to religious facilities in schools. ${ }^{7}$ Cultural injustice, which is more like relational injustice, refers to unfair treatments by people to other because of cultural differences. ${ }^{8}$ This happens without supports from the structure, but often becomes part of the culture of a society and, hence, forms a hidden racism or ethnocentrism. Some example include the view of parents, students and teachers towards school streams (Natural versus Social Sciences), ${ }^{9}$ the erection of worshipping places of minorities, ${ }^{10}$

\footnotetext{
5 Raihani, Creating Multicultural Citizens, pp. 87-88.

6 Iris Marion Young, Justice and the Politics of Difference (Princeton, NJ: Princeton University Press, 1990), p. 26.

7 Raihani, "Minority Right to Attend Religious Education in Indonesia," Al-Jami'ab: Journal of Islamic Studies, 53, 1 (2015), pp. 1-26.

8 Sharon Gewirtz, "Rethinking Social Justice: A Conceptual Analysis," J. Demaine (ed.), Sociology of Education Today (Basingstoke: Palgrave, 2001), pp. 49-64.

9 Raihani, Creating Multicultural Citizens, pp. 179-181.

10 Melissa Crouch, "Religious Regulations in Indonesia: Failing Vulnerable Groups," Review of Indonesian and Malaysian Affairs, 43, 2 (2009), pp. 53-103.
} 
and the perspective and treatment towards Papuan people by other Indonesian people. Often, cultural injustice is crystalized and transformed into a more structural one. For instance, the case of Ahok who was accused of blasphemy represents the transformation of the negative perception of Chinese minority at the community level into structural injustice and discrimination. ${ }^{11}$ More examples of this phenomenon in the context of Indonesian politics and society today can be named. In essence, all the issues suggest that there social justice in various kinds remain pervasive in our society. Not rarely, religion, or interpretation of its teachings, is made as justification for unjust and discriminative views and actions towards other human beings.

Based on the above worrying phenomena, I would like to propose a model of critical approach to teaching practices at the teacher education context. This approach is significantly important for the Islamic education context in Indonesia because: first, teacher is a vital component of the whole process of education as $\mathrm{s} / \mathrm{he}$ contributes to the development of students; second, traditional approach of instruction is not able to provide solutions for most of the social problems in which students will be faced; third, teacher education is a vehicle for preparing teachers so that what happens at the school level is very possibly as a result of the preparation process, and fourth, Islamic teachings strongly endorse equality, justice, and respect for differences which the proposed model is going to promote. The objective of this paper is to invite readers to ponder upon the proposed model, discuss it in academic contexts, and when necessary refine it in order to help the efforts in minimizing social injustice in educational practices. I will start with a brief discussion on the history of Islamic university in Indonesia, a portrayal of teacher education followed by reviews on theories of social reproduction and critical pedagogy. I then propose a new model of critical pedagogy in teacher education along with discussions and justifications.

11 Chang Yau Hoon, Chinese Identity in Post-Suharto Indonesia: Culture, Politics and Media (Brighton: Sussex Academic Press, 2008), p. 8; Daniel Peterson, Islam, Blasphemy, and Human Rights in Indonesia: The Trial of Ahok (New York: Taylor \& Francis Group, 2020), pp. 1-31. 


\section{Islamic University in Indonesia ${ }^{12}$}

The first Islamic higher educational institution established in Indonesia was Sekolah Tinggi Islam (STI) or Islamic College in Jakarta in July $1945 .{ }^{13}$ Since the focus of the nation at that time was on defending its independence from the recapture by Dutch, STI activities in Jakarta. The newly born institution was moved to Yogyakarta following the move of the country's capital city from Jakarta to Yogyakarta. The re-inception of STI in Yogyakarta occurred on April, 10, 1946. The inauguration was marked by the speech by Mohammad Hatta, the newly appointed first vice president of the republic in which he conveyed a message about the characteristics of Islamic university or Sifat Sekolah Tinggi Islam. Two years later, STI transformed into Universitas Islam Indonesia (UII) or Indonesian Islamic University, a university which still exists and flourishes today making it as one of the best Islamic universities in Indonesia. UII until now remains a private university.

The increasing number of pesantren/madrasah graduates had resulted in a specific demand for the establishment of Islamic faculties. This demand was then responded through the transformation of an Islamic faculty within UII in 1950 into Perguruan Tinggi Islam Negeri (PTAIN) or State Islamic University in Yogyakarta. This new university consisted of three faculties, i.e. Tarbiyah (Islamic education), Peradilan (Islamic court system), and Dakwah (Islamic mission). In 1960s, following the popular acceptance of PTAIN marked by the constantly increasing numbers of new students, the government expanded PTAIN into Institut Agama Islam Negeri (IAIN) or State Institute for Islamic Studies, which covered three faculties, i.e. Islamic theology, Islamic law, and Islamic education. In Jakarta, another IAIN was established which had the faculties of Islamic education and Arabic Literature. Since then, many more IAINs were established in various provinces across Indonesia. In 1970s, there were 14 IAINs established in the country.

12 This section was adapted with changes from my paper published in Raihani, "Teacher Education and Multiculturalism in a State Islamic University in Indonesia: A Preliminary Analysis of Its Curriculum and Instruction of Multicultural Education," Z. Seyma Altin (ed.). Ÿ̈lksek Din Öğretimi (Istanbul: Center for Values Education, 2018), pp. 685-700.

13 Hasbullah, Sejarah Pendidikan Islam di Indonesia; History of Islamic Education in Indonesia (Jakarta: Rajawali Press, 1995), pp. 127-140; Mahmud Yunus, Sejarah Pendidikan Islam di Indonesia (Jakarta: Mutiara, 1979), pp. 205-265. 
IAIN was one of the targeted universities for madrasah graduates who particularly aspired to further their education in Islamic disciplines such as Islamic education, Islamic law, Islamic missionary, Islamic theology and so forth. IAIN graduates usually worked in the relevant religious sectors. For instance, graduates of the Islamic education faculty worked in madrasah as teachers, while those of the Islamic law faculty worked in Islamic courts. On one hand, every year, more graduates came and relevant job opportunities got smaller. On the other hand, the increasing worries about the dichotomy of knowledge - sacred (Islamic) and secular - had overwhelmed Muslim thinkers around the globe including those in Indonesia, whilst IAIN had so far indicated no but little efforts to overcome such problems. Therefore, the early 2000s witnessed the transformation of several IAINs into Universitas Islam Negeri (UIN)s or State Islamic University in several areas including Jakarta, Yogyakarta, Malang, Riau and Makassar. UINs are now allowed to open faculties other than religious ones. Some of them established faculties of science and technology, animal husbandry, medicine, psychology and so forth to cater the needs of a larger society. What differentiates UINs from general universities in Indonesia has been the claimed integration of Islamic and secular/general knowledge in their curricula, and it has still been an ongoing effort to develop and achieve a relatively fixed model of the integration. Currently, there are 11 UINs in Indonesia.

\section{Islamic Teacher Education}

As described briefly above, Islamic education faculty is one of the first established within the Islamic university, and in later development, it has become one of the most intended faculties in it. It is not surprising to see that this faculty is the biggest one in the context of Islamic universities or institutes. The reason is that the number of both applicants and students for this faculty has steadily increased over time in almost all faculties of this kind nationally. Under the newly transformed State Islamic Universities, the opening of new study programs within this faculty, which is not limited to the traditional Islamic Religion Education (Pendidikan Agama Islam) and Arabic Language Teaching (Pendidikan Bahasa Arab), has attracted more students to come. Students can study Mathematics Education, Chemistry Education, Indonesian Language Education and so forth in the faculty, which was due to this expansion named the faculty of 
Islamic Education and Teacher Training. The increasing number of applicants for this faculty has also been influenced by the increasing demand for Islamic teachers in schools and madrasah. In other words, the faculty of Islamic Education promises employment in the school and education contexts, perhaps, more convincingly than other faculties under the banner of Islamic universities, institutes and colleges, be they public or private.

The curriculum of the faculty of Islamic education (this term should cover all "names" attributed to this faculty in many Islamic universities, institutes and colleges across Indonesia), at least as it was observed in one of the universities by Sukiman, ${ }^{14}$ has changed more than five times over more than the last three decades. He analyzed that after the year 2004 the curriculum of the faculty was developed by both the central government through the Department of Religious Affairs and the faculty itself. This means the faculty claimed a larger authority to design and develop the curriculum, whilst having to follow general guidelines and standards set by the central government. Another note he made is that the number of course credits students to complete in the post-2004 curriculum is fewer than before, namely 144-156 credits for the whole course. This significantly eased the burden from students who wish to accomplish their study in four years. This curriculum (after 2004 but before 2013) is named "Kurikulum Berbasis Kompetensi" (KBK) or Competency Based Curriculum.

One important dimension of the curriculum that Sukiman did not elaborate further is the KBK curriculum orientation, which is to emphasize more on certain competencies students to master. The introduction of the KBK curriculum by the government in 2004 can be seen as a massive curriculum change which had to be implemented in all levels of schooling from primary to tertiary. This curriculum is a correction to the previous one which was considered to have failed to develop clearly standardized competencies for students to master. Using a scientific approach, this 2004 curriculum defined competency as an observable phenomenon in a form of smart and responsible

14 Sukiman, "Perkembangan Kurikulum Jurusan Pendidikan Agama Islam (PAI) Fakultas Tarbiyah UIN Sunan Kalijaga Yogyakarta Periode 1980-2005," Jurnal Pendidikan Agama Islam, 4, 2 (2009), pp. 99-119. 
actions. ${ }^{15}$ The curriculum was highly oriented for students to achieve vocational skills based on knowledge and values. In teaching and learning, it, therefore, puts a strong emphasis on classroom-based assessment to evaluate how far students have mastered certain competencies using the Audience, Behavior, Condition, and Degree (ABCD) platform.

The above change in the curriculum paradigm had implications on teacher education in Islamic education faculties, or at least one faculty that I have been working in. First, there were socializations through seminars and workshops by the faculty leaders as a result of their learning in Jakarta that students of the faculty need to demonstrate ability in mastering pedagogical competencies which were defined narrowly as teaching skills. Second, as a consequence, subjects deemed to have not facilitated to the achievement of such teaching skills were omitted from the curriculum. This included traditional, but important, subjects such as Logics, Sociology, Anthropology and so forth. Third, pedagogical subjects were added to include those even often overlapping each other. As a result, in my observation, student teachers were adequately equipped with skills of how to teach a particular content of curriculum in a mechanistic fashion, but often lack of critical thinking of why, for example, a particular method used for a specific content. Moreover, they often failed to bring social and cultural realities in classroom. To them, what most important was how to be pedagogically correct.

As a logical consequence, in my observation, students' research interest for their final assignment in this faculty was mostly focused on how to examine a teacher's use of a certain method of teaching in classroom. They problematized low performance of students as a gateway to put forward such a mechanistic pedagogical topic to study in research. They used pedagogical tips explaining "A to Z" steps in using the methods of teaching rather than a theoretical underpinning behind such a method. After that, they used such tips as standards in a form of their research operational concept to measure the investigated teacher against them. They concluded whether or not this teacher complied with their "theoretical standards" of teaching. With a few exceptions, this is typical research conducted by student teachers at the faculty, which reflects its curriculum orientation. The process of

15 Kementerian Pendidikan Nasional, Kurikulum Berbasis Kompetensi (http://www.puskur.or.id/) (accessed on 24 December 2003). 
teaching and learning was considered as a standalone event separated from the real life. Although the KBK curriculum considered highly life skills, the translation of competencies in classroom was limited to such a mechanistic way of thinking and action.

In fact, through the Presidential Regulation Number 8 Year 2012, the government introduced new guidelines for curriculum development called Kerangka Kualifikasi Nasional Indonesia (KKNI) or the Indonesian National Qualification Framework. This curriculum paradigm provides a larger authority for the university to develop curriculum that corresponds to the needs of graduates in the current context. Unfortunately, it has not helped significantly since the practiced development of the curriculum, as I observed, ${ }^{16}$ did not really follow the guidelines. Due to the complexities of the recommended development process, the practices commonly started upside down which is from the selection of subjects (mata kuliah) to the design of study areas (bahan kajian) and graduate profiles, not the way around. Therefore, the outcomes of this new approach to curriculum development have not suggested an improvement in classroom as it has become good on paper only.

\section{Cultural Reproduction and Critical Pedagogy in Teacher Education}

The above observation of the curriculum and practices in Islamic teacher education can predict that graduates of the faculty will hardly possibly be able to bring social realities into their classroom teaching practices. They may consider what happens in classroom as something independent from society, and deliberately create classroom as a place of the imparting of "heavenly" knowledge. Also, they may be uncritical towards social inequalities and injustices that have increasingly occurred nowadays in society as they are obsessed with mechanistic pedagogies to accomplish teaching responsibilities. In several classroom discussions with my students, I found that they were insensitive to issues of, for example, social inequalities entailing the phenomenon of the privatization of education. They praised highly the mushrooming numbers of Islamic integrated schools and the religious educational programs as a manifestation of Islamic

16 In 2014, I was assigned as the head of curriculum development unit in the faculty who was responsible to develop the faculty's curriculum guidelines. The curriculum of each study program is the responsibility of every program leaders and lecturers. 
revivalism. They hardly think of the connection of school education with social issues and problems.

In fact, in connecting education with society, there are several theories of the sociology of education relevant to mention here. First, the structural functionalist theory views education facilitates both reservation and transmission of social values and norms through schooling. School curriculum, therefore, provides students with a set of learning experiences that enable them to function according to what society requires. This implies that students are passive recipients in the process of education who will accept social conformity and not be able to make meaning for themselves. ${ }^{17}$ Second, Giddens et al. ${ }^{18}$ list credentialism as one influential perspective in the sociology of education where credentials in the form of diplomas or certificates are more important than the content of an official curriculum. Such diplomas are needed for securing jobs, even though they are often not relevant to the work involved.

Third, a critical or Marxist theory uncovers another side of education by exploring the role of teacher in reproducing social inequalities. School is not viewed as a neutral place for teachers and students to interact and produce knowledge functional in society, but as a venue where teachers' and students' interaction represents power and knowledge. Classroom portrays social classes and inequalities and then reproduces them. ${ }^{19}$ The mentioned social reproduction works through the hidden curriculum, which means that "students from different social class backgrounds are provided different types of education, both in terms of curricular materials and the kinds of interactions in which they are engaged with teachers." 20 Fourth, as explained in Giddens et al., Bourdieu's view on the role of school in social inequalities differs from the Marxist theory that strictly and directly defines school as reproducing social inequalities. In his view, social inequalities occur because of certain cultural capitals that each

17 Anthony Giddens, Mitchell Duneier, Richard P Appelbaum and Deborah Carr, Introduction to Sociology (New York: W. W. Norton \& Company, Inc., 2012), p. 21.

18 Ibid., p. 461.

19 Pierre Bourdieu and Jean-Claude Passeron, Reproduction in Education, Society and Culture (London: Sage, 1990), pp. 6-10.

20 Henry Giroux and Anthony N. Penna, "Social Education in the Classroom: The Dynamics of the Hidden Curriculum," Theory and Research in Social Education, 7, 1 (1979), pp. 21-24. 
student brings from home to school. In his theory of cultural reproduction, school does not support and teach equal opportunity and social justice as it is a place where most of a culture's dominant discourses are passed on to pupils. The cultural capital - forms of knowledge, education, competences, the advantages and disadvantages that people have as a part of life experiences, peer relationships, and family backgrounds ${ }^{21}$ - that school value is most of the time different from that valued by people in their own communities. In a school where pupils come from different backgrounds, the cultural capital of the school is not equally available to them, and is usually the culture of the economically and culturally advantaged or privileged groups in the community. Thus, certain, mostly dominant, cultures are reproduced in school, which then lead to social inequalities.

The above sociological perspectives reveal the close relationship between education and society. Classroom can be described as a miniature of society around the school, and divorcing it from the living society is to miss the central point of education. School has to be transformative in a way that it contributes to the betterment of society, narrowing the gap of inequalities and minimizing social injustice and its impacts. The current shape of Islamic teacher education as depicted above unfortunately unlikely equip student teachers with this awareness. The bold emphasis on mechanistic pedagogies, as both the curriculum and my teaching experiences suggest, take them away from developing critical thinking over social inequalities that happen in the Indonesian multicultural society as indicated early in the introduction. This situation resembles what Bartolomé2 ${ }^{2}$ says about the condition of the United States' teacher education as follows:

Gaining access to and actively creating methods and materials for the classroom is certainly an important step towards effective teaching. However, this practical focus far too often occurs without examining teachers' own assumptions, values, and beliefs and how this ideological posture informs, often unconsciously, their perceptions and actions when working with linguisticminority and other politically, socially, and economically subordinated students.

\footnotetext{
21 Pierre Bourdieu, "The Forms of Capital," J. Richardson, Handbook of Theory and Research for the Sociology of Education (New York: Greenwood, 1986), pp. 47-51.

22 Lilia I Bartoleme, "Critical Pedagogy and Teacher Education: Radicalizing Prospective Teachers," Teacher Education Quarterly, Winter (2004), p. 97.
} 
Therefore, there should be change proposed to the existing pedagogy in the Islamic teacher education by promoting critical pedagogy approach. Through this approach, students would be invited to ponder upon their future teaching assumptions, values, beliefs and philosophies, and how these would influence their teaching practices. Through this as well, they would develop critical thinking of society as a whole and work on promoting social inequalities.

\section{The Proposed Model}

Critical pedagody is best defined by McKernan in which "Critical pedagogy is a movement involving relationships of teaching and learning so that students gain a critical selfconsciousness and social awareness and take appropriate actionagainst oppressive forces." 23 Critical pedagogy was first attributed to Paulo Friere, ${ }^{24}$ particularly in his work "Pedagogy of the Oppressed", in which he criticized teaching approaches that maintain the status quo and fail to empower pupils to have critical thinking and awareness of social issues and injustices. Education in this way is like a banking process ("banking education"), depositing knowledge into passive students. Critical pedagogy, therefore, wants to challenge and change structural and cultural inequalities in school, respects differences and promotes equalities, incorporates a moral vision to un-oppress the oppressed, and to question one-self and one's society. By doing so, school eventually may become a place for promoting social equality and justice in society increasingly marked by diversity.

Critical pedagogues develop five steps of the critical praxis employed in teaching practices which should engage both teachers and students. The five stages include: identifying a problem, analyzing the problem, creating a plan of action to address the problem, implement the plan of action, and analyzing and evaluating the action. In classroom, this critical praxis mandates that its instruction should be developed on the existing knowledge of students and should utilize it for benefit of current learning. In essence, students construct their own knowledge and awareness through meaningfully challenging

\footnotetext{
23 James McKernan, "The Origins of Critical Theory in Education: Fabian Socialism as Social Reconstructionism in Nineteenth-Century Britain," British Journal of Educational Studies, 61, 4 (2013), p. 425.

24 Paulo Freire, Pedagogy of the Oppressed (New York and London: Continuum, 1970), p. 25.
} 
interactions with society in order to solve problems of inequalities. This strongly indicates that classroom and society are closely connected, teachers are critically aware of both dominating and oppressed cultures in both places, and engage students in corresponding activities.

Diagram 1. The Critical Pedagogy Model for Islamic Teacher Education

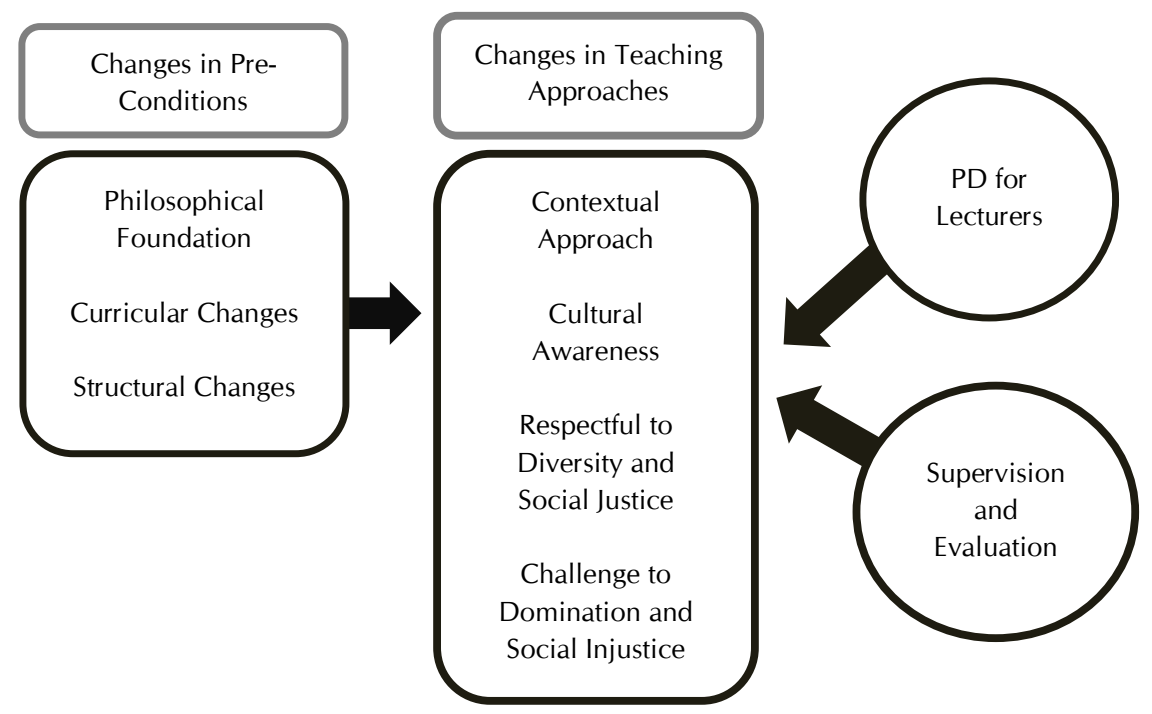

As Diagram 1 suggests, the model starts with a very fundamental aspect of education, i.e. changes in teaching philosophical foundations. Teaching philosophy of student teachers need to be oriented to support critical pedagogy, which is not at all the process of knowledge transfer like in the traditional mode of instruction. It is a process by which students construct knowledge by utilizing resources and existing knowledge. Student teachers should understand well the principle of constructivism theory as a basis for their teaching practices in combination with a critical way to develop consciousness of social realities. Traditional teaching philosophy which puts emphasis on teacher-centered approaches is no longer appropriate as it stifles students' critical thinking capacity and imposes obedience and loyalty to what they are limited to reason. So, the philosophy of teaching in supporting critical pedagogy considers education as a process of humanizing human beings. 
In the Islamic context, the change of teaching philosophy into a more student-centered approach and critical pedagogy is not baseless. The Quran and the Sunnah have provided inspirations of how education should liberate people from myths and other non-tawhidic beliefs, how education enables people to independently think and construct knowledge by pondering upon and researching nature and realities, how education should develop awareness in people about social justice, and so forth. ${ }^{25}$ Education in Islam is directed to create an independent individual who will be responsible for his or her actions not only in the world but also in hereafter. The relationship between teacher and student in Islamic history which is often described as refraining students from critical thinking because they are instructed to obey whatever teachers command is not fully understood correctly. In my view, such relationship does not prohibit students from critically thinking or asking challenging questions, but is more about respectful interactions from students to teachers. In the history of Islamic learning, discussions and debates were used as part of the constructive learning methods by Islamic scholars. ${ }^{26}$ Therefore, critical pedagogy stands very strongly on the very basis of Islamic teachings which suggest that education should lead to social transformation of just and democratic society.

The change in philosophical foundations as indicated above should lead to curricular changes. Curriculum of teacher education should be developed and designed as a whole to promote independence, critical thinking, respect for differences and social justice. In a simplistic way, the curriculum should infuse several critical subjects such as social and cultural theories, sociology and anthropology. As explained previously, these subjects were actually part of the curriculum decades ago and omitted for the sake of more behavioristic approaches the $\mathrm{KBK}^{27}$ curriculum adheres to. In its argument, the KBK curriculum should outline students' competencies that are empirically observable such as teaching skills. Therefore, teaching of such critical subjects was not recommended.

\footnotetext{
25 Syed Muhammad Naguib al-Attas, Aims and Objectives of Islamic Education (Jeddah: King Abdulaziz University, 1979), pp. 2-10.

${ }_{26}$ George Makdisi, The Rise of Colleges: Institutions of Learning in Islam and the West, (Edinburgh: Edinburgh University Press, 1981), pp. 12-20.

$27 \mathrm{KBK}$ is the acronyme of Kurikulum Berbasis Kompetensi, Competences Based Curriculum.
} 
In the Islamic education context, Quranic exegesis and the prophet's traditions should in a larger part include and explore that Islam is a religion of justice, equality, and non-discrimination. Unlike the current tendency of Indonesian Islam, 28 "positive and polite faces" of Islam should color predominantly the content of the curriculum, and minimize the use of historical excerpts that contains violence. If stories of wars and battles are to be included, appropriate contexts should be provided to enable students' understanding that the whole message of the Islamic religion is justice, peace and harmony. Students need to be invited to ponder upon Islamic teachings through prophetic stories about recognizing and respecting diversity, valuing tolerance, and defending rights of people regardless of their majority or minority status.

Organizational structure of teacher education should also reflect the above changing teaching philosophy. Those who are in power should develop vision and awareness of social justice education and share this vision to others. Governance and management are to be practiced with fully acknowledging equal opportunity of people of different backgrounds. There should be discouragement from using ethnocentrism in recruitments, evaluation and promotions. Meritocracy is the norm of organization, but affirmative approaches to empower powerless individuals or groups of people should also be employed to ensure that there is no domination by those who feel to have privileges because of group affiliations or numbers. Student teachers should experience this just and fair context with full comprehension that the structure is consciously designed for that purpose. When appropriate, supporting policies should be issued to redesign the desired structure.

The changes in the pre-conditions above should bring about changes in teaching approaches in the teacher preparation program, and thus, these approaches should be used first by lecturers in teaching practices and second be practiced by student teachers. There are four characteristics of teaching approaches that this model proposes. These characteristics resemble the five stages of the critical praxis as suggested in the critical pedagogy approach. First, teaching approaches

28 Martin van Bruinessen (ed), Contemporary Developments in Indonesian Islam: Explaining The 'Conservative Turn' (Singapore: Institute of Southeast Asian Studies, 2013); Greg Fealy, A Conservative Turn www.insideindonesia.org/a-conservative-turn, p. 4. 
should be contextual. ${ }^{29}$ This is commonly termed as a contextual teaching and learning (CTL) approach which is defined as facilitating students to make meaning of subjects being taught with the connection with the real world, which does not always go without problems including social injustices. Learning materials are not designed in an ivory tower, but students need to construct knowledge through experiencing learning processes that have useful relations with real life applications. CTL will equip students with an ability to critically analyze the contexts - identifying problems and finding alternative solutions by utilizing contextually immediate resources. CTL in many ways supports critical pedagogy.

Second, student teachers in this model are required to develop awareness of cultural differences and their consequences on social inequalities. They have to develop understanding and belief that no one deserves different treatments that degrades their dignity as human beings in the contexts of education and other because of coming from different cultures. Teachers who have cultural awareness will demonstrate eagerness to understand every student's ethnic and religious backgrounds, care about their cultural, emotional, and intellectual needs. ${ }^{30}$ So, having cultural awareness does not only mean to understand that there are differences in culture, but beyond that, requires pro-active engagement by teachers to understand cultural distinctiveness of every student and take actions correspondingly by ensuring that one's culture is equally respected and recognized

Third, pertinent to the cultural awareness, in teaching practices, student teachers are trained to respect students' diversity and to promote social justice. Every pupil is unique and autonomous, ${ }^{31}$ and therefore construct diversity. In the constructivism theory, every child brings a set of potentials, capacity and information by which she or he uses to understand lessons taught in school or to construct new

${ }^{29}$ Robert G. Berns and Patricia M. Erickson, "Contextual Teaching and Learning: Preparing Students for the New Economy," The Highlight Zone: Research \& Work, 5 (2001), pp. 2-9.

30 James A Banks, "Multicultural Education: Characteristics and Goals," James A Banks and Cherry A. McGee Banks (eds), Multicultural Education: Issues and Perspectives (New Jersey: Wiley, 2010), pp. 5-10; James A Banks (ed.), The Routledge International Companion to Multicultural Education (New York and London: Routledge Taylor \& Francis Group, 2011).

31 George E. Hein, "Constructivist Learning Theory," The Museum and the Needs of People (Jerussalem: CECA Conference, 1991), p. 3. 
knowledge. Child's uniqueness come from birth, culture, parents' economics backgrounds, social networks and so forth. Teachers who have developed this ability to respect to these embedded characteristics of students will serve as facilitators to provide an ample opportunity to develop their potentials. They will strive to appropriate teaching strategies to such individual characteristics.

Therefore, student teachers who experience a learning process in the teacher education context should be exposed to the importance of social justice and different ways of promoting it. In the Indonesian context, examples of how people struggle to receive just treatment by the state are not a few. Both immediate and broader context of society where student teachers live expose them to various events of social injustice. Hartanto, Nadia \& Septiati recorded several cases of how poor people experienced injustice before the law. ${ }^{32}$ For example, a grandmother in Banyumas was sentenced to 1.5 years because of stealing cocoa fruits the value of which is no more than Rp. 10,000. In their works on education and health services in Indonesia, Blunt, Turner \& Lindroth found that patronage in varying degrees contributed to the enactment of corrupted service deliveries and, hence, perpetuated social injustice. ${ }^{33}$ Just to mention an example of their findings, staff promotion will not go smoothly without patronage in one or more various forms such as having a good relationship with superior or in some cases paying bribery for approaching someone who can provide assistance for promotion. All of these examples should be brought to classroom of teacher education to enable students to ponder upon problems arising in their society and alternative solutions.

Fourth, after being exposed to events of injustice, student teachers are invited to identify the problems and their roots or factors, which in the practices of injustice and discrimination lay in the domination of one group over another. ${ }^{34}$ Domination sources from various types of

32 Naomi Jesica Hartanto, Meta Nadia and Lusi Septiani, "The Realization of Social Justice for Underprivileged People in Legal Philosophy," Legal Spirit, 2, 2 (2018), p. 5.

33 Peter Blunt, Mark Turner and Henrik Lindroth, "Patronage, Service Delivery, and Social Justice in Indonesia," International Journal of Public Administration, 35, 3 (2012), pp. 214-220.

34 Joan G. DeJaeghere, "Critical Citizenship Education for Multicultural Societies," Interamerican Journal of Education for Democracy, 2, 2 (2009), pp. 223-236; Mehdi Shokouhi and Farnaz Pashaie, "Critical Pedagogy and Its Realization in Classroom Context," Journal of Applied Linguistics and Language Research, 2, 3 (2015), pp. 204-210. 
privileges acquired by or given to the dominant group, and this may come from the majority status, wealth, and traditional powers. In practice, student teachers invite students to analyze social problems by identifying factors contributing to the problems and developing action plans for solving the problems. Many students are simply not aware of social realities due to myopic attitudes as they are not aroused by the lecturers about the realities and not given tools to see the phenomena differently. However, challenging domination can be uneasy or uncomfortable for many people particularly those who have enjoyed the privileges. Therefore, the success really depends on the ways teachers set strategies in order to minimize resistances and discomfort by the traditionally dominant groups.

In many contexts, domination often manifests in the complex majority-minority relationship. Majority tends to have more privileges in terms of access to social justice than minority does. In a democratic system, majority often has the power to decide on rules and regulations that dictate and bind all members of society. If this power is not used with care and respect towards minority, suppression and discrimination may happen since minority does not have the power to balance the majority's aspiration. However, majority does not necessarily mean numbers. Quantitative majority, in some contexts, may not have the power even in self-determination. For instance, in one context, a Catholic school whose Catholic students and teachers are minority made the Catholic religion class as compulsory on all students, the majority of which are Protestants and Muslims. Non-Catholic students had to attend prayers in the school Church. ${ }^{35}$

Through the examples of events of both social justice and injustice student teachers in the context of Islamic teacher education learn how and why injustice occurs in society. They will identify which groups potentially dominate others and what factors interplay in the events of domination. Under the guidance of lecturers, they should develop ways to challenge such domination and anticipate possible and potential consequences. They should also learn to develop counternarrations to what regularly presented to them in social media by the dominating groups. In short, student teachers should be enabled to defend the rights of marginalized people against oppression in order to promote social justice.

35 Raihani, Creating Multicultural Citizens, pp. 117-120. 
It is important for both lecturers and students at the Islamic teacher education context to understand well that in Islam, justice is one of the central themes mentioned in many verses of the Qur an and the Prophet's traditions. Among the verses is "Indeed, We sent Our Messengers with clear proofs and revealed with them the Scripture and the Balance (justice) that mankind may keep up." 36 The Prophet Muhammad also included a just ruler as one of the seven categories of people whom God will shelter under His shade on the Day of Judgement. The concept of justice in Islam should be understood in the context of the Muslim community Islam has aspired for-a community in which the members submit themselves to the will of Allah. John L. Esposito ${ }^{37}$ explains, "The Qur'an envisions a society based on the unity and equality of believers, a society in which moral and social justice will counterbalance oppression of the weak and economic exploitation". The earth belongs ultimately to Allah, who granted human beings a responsibility to take care of it. Islam acknowledges individual rights and possessions, but all are restricted by laws to ensure equal distribution to every member of its society.

Modern sociologists identify three types of justice-distributive, cultural, and associational. Distributive justice will only be possible only if the absence of exploitation, marginalization, and deprivation can be ensured. Cultural justice occurs when every culture in society is valued and recognized to the extent that there is no cultural domination and no disrespect to any culture. Associational justice is seen as: "the absence of patterns of association amongst individuals and amongst groups which prevent some people from participating fully in decisions which affect the conditions within which they live and act." "38 These three types of justice cover issues that may arise amongst those who are dissatisfied with a broad range of social conditions, including economic, cultural, and political conditions, and relations amongst individuals as well as between groups. Thus, these

\footnotetext{
36 Muhammad Tajuddin Al-Hilali and Muhammad Muhsin Khan, Interpretation of the Meanings of the Noble Qur'an in the English Language (Riyadh: Maktabah Dar-us Salam, 1994), p. 743; QS 57:25

37 John L. Esposito, Islam the Straight Path (New York and Oxford: Oxford University Press, 1998), p. 29.

38 S. Power and Sharon Gewirtz, "Reading Education Action Zones," Journal of Education Policy, 16, 1 (2001), p. 41.
} 
three types of social justice are concerned not only with individuals in society but also with groups and their relations with others.

To support the changes to happen as expected above, this model suggests two inseparable supporting programs to Islamic teacher education, namely: professional development of the lecturers and evaluation and supervision of their teaching practices. Not every lecturer understands critical pedagogy. Therefore, seminars and workshops on how to use critical pedagogy in their teaching practices are of urgency. Also, efforts to enable lecturers to sharpen their social analysis to provide solutions to problems should be done. Inseparably, evaluation and supervision system should be in place to ensure that lecturers' teaching processes effectively use a critical pedagogy approach, and if not, the system will be able to detect problems and inform alternative solutions to improve teaching practices.

\section{Conclusion}

The above model is an impetus of a potential future model proposed to equip student teachers with critical ability to later in their workplaces become effective agents for social justice through teaching processes in the context of Islamic education. The model resembles the aspiration of moving out from traditional teaching practices which tend to reproduce inequalities to critical pedagogy that promotes social justice. It connects classroom with social realities and problems, and mandates both teachers and students to critically think beyond classroom and to be actively engaged with actions in minimizing inequalities and injustice in their immediate and broader society. It invites both of them to challenge domination of certain groups over others. However, one limitation of this model is that it has not been tested empirically through a proper research and development approach, but it serves as a useful trigger for further development.

Keeping the limitation in mind, the proposed model can serve as one of the strategies by the government particularly the Ministry of Religious Affairs in mainstreaming Islamic moderation in education. Islamic moderation is a way of thinking, attitude and behavior to place the self in the middle of two extremes and hold justice. It rejects the idea of domination of one to another as everyone is equal before God. Islamic moderation commands respect and recognition of differences since the Qur'an informed that diversity is the will of Allah. So, the model can help the moderation process in the context of education. 
Islamic moderation will not be fruitful if teaching practices in Islamic education remain unchanged and supportive to the majority domination. Therefore, the Ministry should consider adoption and adaptation of a critical pedagogy approach in the curriculum of institutions from lower to higher education.

It can be expected that two types of challenges can be a hindrance to successful implementation, namely: ideological and technical. Some lecturers and student teachers or even faculty leaders may challenge the application of the model on the basis of Islamic ideology by accusing that the model is a strategy to weaken Islam and Muslims. They believe that Islam should be dominating as no other faith is above it. I have often encountered this group of people in my classes, and they can be many. The way to face with this group is to use the supports of Islamic teaching to counter their arguments. In fact, Islam in its moderate interpretation upholds very highly justice and commands its people to do justice even to non-Muslims. As argued above, the critical pedagogy is strongly based in Islam, and it is the lecturers or advocates to dig and deepen understanding of its teachings and use them to convince others.

With technical challenges, the way to overcome is to develop workshops and trainings so that all relevant stakeholders get used to and have the capacity to be actively engaged in the model application. The process will follow through the logics of change, i.e. initiation, implementation and institutionalization. In short, challenges are real and it will take time to successfully implement the model and see it fruitful. In a long run, through an appropriate pedagogical approach, Indonesian Islamic education would be able to bring about changes to advocate social justice in society, and become an excellent model in the global context. []

\section{References}

Al-Attas, Syed Muhammad Naguib, (ed). Aims and Objectives of Islamic Education. Jeddah: King Abdulaziz University, 1979.

Banks, James A. (ed). The Routledge International Companion to Multicultural Education. New York and London: Routledge Taylor \& Francis Group, 2011. 
. "Multicultural Education: Characteristics and Goals." James

A Banks and Cherry A McGee Banks (eds). Multicultural Education: Issues and Perspectives. New Jersey: Wiley, 2010. pp. 5-10.

Bartoleme, Lilia I. "Critical Pedagogy and Teacher Education: Radicalizing Prospective Teachers." Teacher Education Quarterly Winter (2004).

Berns, Robert G, and Patricia M Erickson. "Contextual Teaching and Learning: Preparing Students for the New Economy." The Highlight Zone: Research \& Work, 5 (2001), pp. 2-9.

Blunt, Peter, Mark Turner, and Henrik Lindroth. "Patronage, Service Delivery, and Social Justice in Indonesia." International Journal of Public Administration, 35, 3 (2012), pp. 214-220.

Bourdieu, Pierre. "The Forms of Capital." J. Richardson. Handbook of Theory and Research for the Sociology of Education. New York: Greenwood, 1986. pp. 47-51. -. and Jean-Claude Passeron. Reproduction in Education, Society and Culture. London: Sage, 1990.

DeJaeghere, Joan G. "Critical Citizenship Education for Multicultural Societies." Interamerican Journal of Education for Democracy, 2, 2 (2009), pp. 204-210.

Esposito, John L. Islam the Straight Path. New York and Oxford: Oxford University Press, 1998.

Fealy, Greg. A Conservative Turn. Available at www.insideindonesia.org/ a-conservative-turn.

Freire, Paulo. Pedagogy of the Oppressed. New York and London: Continuum, 1970.

Gewirtz, Sharon. "Rethinking Social Justice: A Conceptual Analysis". J. Demaine (ed.). Sociology of Education Today. Basingstoke: Palgrave, 2001. pp. 49-64.

Giddens, Anthony, Mitchell Duneier, Richard P. Appelbaum and Deborah Carr. Introduction to Sociology. New York: W. W. Norton \& Company, Inc., 2012.

Giroux, Henry and Anthony N. Penna. "Social Education in the Classroom: The Dynamics of the Hidden Curriculum." Theory and Research in Social Education, 7, 1 (1979), pp. 21-24. 
Hartanto, Naomi Jesica, Meta Nadia and Lusi Septiani. "The Realization of Social Justice for Underprivileged People in Legal Philosophy." Legal Spirit, 2, 2 (2018).

Hasbullah. Sejarah Pendidikan Islam di Indonesia; History of Islamic Education in Indonesia. Jakarta: Rajawali Press, 1995.

Hein, George E. "Constructivist Learning Theory." The Museum and The Needs of People. Jerussalem: CECA Conference, 1991.

Hoon, Chang Yau. Chinese Identity in Post-Suharto Indonesia: Culture, Politics and Media. Brighton: Sussex Academic Press, 2008.

Makdisi, George. The Rise of Colleges: Institutions of Learning in Islam and the West. Edinburgh: Edinburgh University Press, 1981.

McKernan, J. A. "The Origins of Critical Theory in Education: Fabian Socialism as Social Reconstructionism in Nineteenth-Century Britain." British Journal of Educational Studies, 61, 4 (2013), pp. 417-433.

Muhammad Tajuddin Al-Hilali and Muhammad Muhsin Khan. Interpretation of the Meanings of the Noble Qur'an in the English Language. Riyadh: Maktabah Dar-us Salam, (1994)

Parker, Lyn, and Chang Yau Hoon. "Secularity, Religion and the Possibilities for Religious Citizenship." Asian Journal of Social Science, 41, 2 (2013), pp. 150-174.

Peterson, Daniel. Islam, Blasphemy, and Human Rights in Indonesia; The Trial of Ahok. New York: Taylor \& Francis Group, 2020.

Power, Sally and Sharon Gewirtz. "Reading Education Action Zones." Journal of Education Policy, 16, 1 (2001), pp. 39-51.

Raihani. "Education for Multicultural Citizens in Indonesia: Policies and Practices." Compare: A Journal of Comparative and International Education, 48, 6 (2018), pp. 992-1009.

-. "Minority Right to Attend Religious Education in Indonesia." Al-Jami'ah: Journal of Islamic Studies, 53, 1 (2015), pp. 1-26.

-. "Teacher Education and Multiculturalism in a State Islamic University in Indonesia: A Preliminary Analysis of Its Curriculum and Instruction of Multicultural Education." Z. Seyma Altin (ed.). Yüksek Din Ögrretimi. Istanbul: Center for Values Education, 2018. pp. 685-700. 
Creating Multicultural Citizens: A Portrayal of Contemporary Indonesian Education. New York: Routledge, 2014.

Shokouhi, Mehdi and Farnaz Pashaie. "Critical Pedagogy and Its Realization in Classroom Context." Journal of Applied Linguistics and Language Research, 2, 3 (2015), pp. 204-210.

Smith, Claire Q. The Roots of Violence and Prospects for Reconciliation: $A$ Case Study of Ethnic Conflict in Central Kalimantan, Indonesia. Washington, DC: The World Bank, 2005.

Sukiman. "Perkembangan Kurikulum Jurusan Pendidikan Agama Islam (PAI) Fakultas Tarbiyah UIN Sunan Kalijaga Yogyakarta Periode 1980-2005." Jurnal Pendidikan Agama Islam, 4, 2 (2009), pp. 99-119.

The World Bank. Indonesia's Rising Divide. Jakarta: The World Bank, 2016.

van Bruinessen, Martin (ed.). Contemporary Developments in Indonesian Islam: Explaining The "Conservative Turn". Singapore: Institute of Southeast Asian Studies, 2013.

Wilson, Chris. Ethno-Religious Violence in Indonesia: From Soil to God. London: Routledge Taylor \& Francis Group, 2008.

Young, Iris Marion. Justice and the Politics of Difference. Princeton, NJ: Princeton University Press, 1990.

Yunus, Mahmud. Sejarah Pendidikan Islam di Indonesia. Jakarta: Mutiara, 1979. 